\title{
Reabilitação vestibular em idosos com tontura*******
}

\author{
Vestibular rehabilitation in elderly patients with dizziness
}

\author{
Francisco Halilla Zanardini* \\ Bianca Simone Zeigelboim** \\ Ari Leon Jurkiewicz*** \\ Jair Mendes Marques**** \\ Jackeline Martins-Bassetto******
}

*Fisioterapeuta. Mestre em Distúrbios da Comunicação pela Universidade Tuiuti do Paraná. Professor da Faculdade Integrada Espírita. Endereço para correspondência: Rua Professor Doracy Cesarino, 586 Apto, 12 - Curitiba - PR - CEP 80.320-200 (deltaclinica@ibest.com.br).

**Fonoaudióloga. Doutora em Ciências dos Distúrbios da Comunicação Humana pela Escola Paulista de Medicina. Coordenadora do Programa de Mestrado em Distúrbios da Comunicação da Universidade Tuiuti do Paraná.

****aédico. Doutor em Anatomia pela Escola Paulista de Medicina. Professor do Programa de Mestrado da Universidade Tuiuti do Paraná.

*****ngenheiro. Doutor em Ciências Geodésicas pela Universidade Federal do Paraná. Professor do Programa de Mestrado em Distúrbios da Comunicação da Universidade Tuiuti do Paraná.

*****Fonoaudióloga

*******Pesquisa Realizada no Setor de Otoneurologia da Universidade Tuiuti do Paraná.

Artigo de Pesquisa

Artigo Submetido a Avaliação por Pares

Conflito de Interesse: não

Recebido em 05.01.2006.

Revisado em 27.03.2006; 28.09.2006;

25.04.2007.

Aceito para Publicação em 25.04.2007.

\section{Abstract}

Background: the aging of the population is a natural process and is manifested by a decline in the functions of several organs. Vestibular rehabilitation (VR) is a therapeutic process that seeks to promote a significant reduction in the symptoms of the labyrinth. Aim: to verify the benefits of VR exercises through the application of the Dizziness Handicap Inventory (DHI) questionnaire - Brazilian version - pre and post rehabilitation. Method: participants of this study were eight elderly patients with dizziness, ages between 63 and 82 years, three male and five female. The following procedures were carried out: medical history, otologic inspection, vestibular evaluation with vectoelectronystagmography (VENG), application of the DHI questionnaire and of the Cawthorne (1944) and Cooksey (1946) VR exercises. Results: regarding the auditory and vestibular complaints which were referred to in the medical history, the following was observed: presence of tinnitus, hearing loss, postural vertigo and of unbalance. In the evaluation of the vestibular function alterations were observed for all of the participants, mainly in the caloric test, with a prevalence of unilateral and bilateral hypofunction. In the vestibular exam the following was observed: three cases of unilateral peripheral vestibular deficit syndrome, three cases of bilateral peripheral vestibular deficit syndrome, one case of bilateral central vestibular deficit syndrome and one case of irritating bilateral central vestibular syndrome. There was a statistically significant improvement of the following aspects after VR: physical $(p=0.00413)$, functional $(p=0.00006)$ and emotional $(p=0.03268)$. Conclusion: the VR protocol favored the improvement of life quality of the participants and was of assistance in the process of vestibular compensation.

Key Words: Vestibular Diseases; Rehabilitation; Vestibular Function Tests; Elderly.

\section{Resumo}

Tema: o envelhecimento populacional é um processo natural, manifesta-se por um declínio das funções de diversos órgãos. A reabilitação vestibular (RV) é um processo terapêutico que visa promover a redução significativa dos sintomas labirínticos. Objetivo: verificar os benefícios dos exercícios de RV por meio da avaliação pré e pós-aplicação do questionário Dizziness Handicap Inventory (DHI) adaptação brasileira. Método: participaram deste estudo oito idosos com queixa de tontura, na faixa etária de 63 a 82 anos, três do sexo masculino e cinco do sexo feminino. Realizaram-se os seguintes procedimentos: anamnese, inspeção otológica, avaliação vestibular por meio da vectoeletronistagmografia (VENG), aplicação do questionário DHI e dos exercícios de RV de Cawthorne (1944) e Cooksey (1946). Resultados: com relação as queixas auditivas e vestibulares, observou-se a incidência do zumbido, da hipoacusia, da vertigem postural e do desequilíbrio; na avaliação da função vestibular, constataram-se alterações em todos os idosos; as alterações foram na sua maioria na prova calórica com predomínio da hiporreflexia uni e bilateral; constataram-se, no exame vestibular, três casos de síndrome vestibular periférica deficitária unilateral, três casos de síndrome vestibular periférica deficitária bilateral, um caso de síndrome vestibular central deficitária bilateral e um caso de síndrome vestibular central irritativa bilateral; houve melhora significativa dos aspectos físico $(\mathrm{p}=0,00413)$, funcional $(\mathrm{p}=0,00006)$ e emocional $(\mathrm{p}=0,03268)$ após a realização dos exercícios de RV. Conclusão: o protocolo utilizado de RV promoveu melhora na qualidade de vida dos idosos e auxiliou no processo de compensação vestibular.

Palavras-Chave: Doenças Vestibulares; Reabilitação; Testes de Função Vestibular; Idoso.

Referenciar este material como:

ZANARDINI, F. H.; ZEIGELBOIM, B. S.; JURKIEWICZ, A. L.; MARQUES, J. M.; BASSETTO, J. M. Vestibular rehabilitation in

$\sum 3$ elderly patients with dizziness (original title: Reabilitação vestibular em idosos com tontura). Pró-Fono Revista de Atualização Científica, Barueri (SP), v. 19, n. 2, p. 177-184, abr.-jun. 2007. 


\section{Introduction}

Human life expectancy has increased from 50 to 74.5 years since the beginning of the last century. Accompanying this growth, Brazil enjoys an increasing elderly population due to improvements in public health conditions and medical advances. Brazil is rated number 6 in the world in the number of elderly citizens, approximately 32 million, as stated by the World Health Organization (WHO). According to WHO, in 2025 there will be two billion people of 60 years and over in the world (Gazeta do Povo Newspaper, 2004).

Population aging is a natural process, manifested by a decline in the functioning of several organs which, characteristically, tends to press forward with time, with one not being able to define an exact transition point, as in the other phases. There is a relatively advanced beginning at the end of the second decade of life until the first functional and/or structural alterations, attributed to aging, well forth. (Guccione, 2002).

It is known that aging diminishes vitality and hence favouring the onset of diseases, the most prevalent being the alterations of vestibular and sensorial origin, cerebrovascular and cardiovascular dysfunction, metabolic diseases, cervical and neurological alterations, (in the degenerative diseases, the dementia syndromes are the most obvious), bone disease and others. (Nadol e Schuknecht, 1989; Zeigelboim et al., 2001). Concerning the adult diseases, cerebral changes in the senses due to vascular alterations, rank among the most frequent (Zeigelboim et al., 2004). These multiple causes associated with the aging of the vestibular system, characterize the multifactorial nature dizziness in the elderly. Concerning the sensorial alterations dizziness is highlighted, being common in all age groups especially in the elderly and in women. Dizziness constitutes the second most prevalent symptom, losing in predominance to migraines from 65 years and over. In patients 75 years and over, dizziness is the most prevalent symptom, of approximately $80 \%$. Alterations in postural control in the elderly induce a greater risk of falls and the consequent side effects which reveal an elevated morbidity (Simoceli et al., 2003).

Corporal balance depends on the integrity of the vestibular system (labyrinth, vestibulocochlear nerve, nuclei, vessels and inter-relations in the central nervous system), the somatosensory system (sensory receptors located in tendons, muscles and joints) and vision. The labyrinth is responsible for the balance and positioning of the body in space. Dizziness and/or imbalance intensify when something interferes with the normal functioning of the corporal balancing system, originating peripherally or centrally (Jurkiewicz et al., 2002).

Aging compromises the functioning of the central nervous system as it accomplishes processing of vestibular, visual and proprioceptive signals responsible for maintenance of corporal balance, as well as diminishing the capacity of the adaptive reflexes to change (Nadol e Schuknecht, 1989).

The principal methods of treatment for vestibular dysfunction are chemical, surgical and vestibular rehabilitation (RV) (Ganança e Ganança, 2001). RV has been shown to act physiologically upon the vestibular system as a therapeutic remedy as a consequence of its method of operation based on central mechanisms of neuro plasticity known as adaptation, habituation and substitution to achieve vestibular compensation.

The RV exercises endeavour to improve vestibulo visual interaction during head movements, amplify static and dynamic postural stability in conditions which produce conflicting sensory information and diminish individual sensitivity to head movements (Ganança e Ganança, 2001; Rezende et al., 2003). RV can promote a complete cure in $30 \%$ of the cases and differing degrees of improvement in $85 \%$ of the patients (Ganança e Ganança, 2001). It is very important to emphasize that this problem has an effect on a large number of the elderly and has been gradually increasing all over the world. Since dizziness is one of the most common sensory symptoms among the elderly, the objective of this paper was to verify the benefits of RV exercises by means of a "pre" and "post" application of the Dizziness Handicap Inventory (DHI) questionnaire adapted to Brazilian standards.

\section{Method}

This paper was approved by the Institutional Ethics Committee in appraisal number 082/2004. Authorization was obtained by the patients or guardians by virtue of their signature of the document Terms of Free and Informed Consent. Eight elderly subjects were evaluated, in the age group 63 to 82, 3 male and 5 female, with complaints of dizziness of varying aetiology, referred from the retirement home "Nosso Lar Comunidade do 
Idoso", located in Almirante Tamandaré in the metropolitan region of Curitiba, in the state of Paraná.

The casuistry was reduced due to the fact that nine elderly citizens from the retirement home with complaints of dizziness, were incapacitated and with their age and other existing ailments, not only was transport for the labyrinthian exams made impossible but also the completion of the rehabilitation exercises, with risks of falls and fractures which could lead to various complications including death.

All the subjects who participated in the research were shown to be in the descendent audiometric curve of the neurosensory type in the audiologic evaluation.

The patients were submitted to the following procedures:

Anamnesis: a questionnaire was administered with emphasis upon oto neurological signs and symptoms and family and personal background. Elderly patients with important neurological, psychological, visual, muscular and other disorders which restrained the accomplishment of a vestibular exam, as well as the applicability of RV exercises, were excluded.

Otorhinolaryngological exam: carried out with the objective of ruling out any alteration which could affect the exam.

Vestibular evaluation: the patients were submitted to the following tests which constitute the vestibular exam before the therapeutic process: without registry- the vertigo and nystagmus of positioning were investigated; the spontaneous and semi-spontaneous nystagmus with eyes open, from the front and at a 30 degree deviation to the right, left, upwards and downwards was also investigated.

With registry: for the completion of the Vectoelectronystagmography (VENG), a Berger thermo sensitive device, model VN316 with 3 registry channels was utilised. After cleaning the skin in the periorbital regions with rubbing alcohol an active electrode was placed in the lateral angle of each eye and on the frontal middle line and bonded with electrolytic paste, forming an isosceles triangle, which allowed the identification of horizontal, vertical and oblique ocular movements. This type of VENG granted the possibility of obtaining more accurate speed measurements of the slow component (vestibular correction) of nystagmus.

A Ferrante pendular rotatory chair was utilized, from a Neurograff visual stimulator, model EV VEC, and from a Neurograff air otocalorimeter, model NER 05 , with air temperatures of 42,18 and 10 degrees
Celsius for the caloric tests.

The following ocular and labyrinthian tests were performed with VENG, according to the criteria of Mangabeira-Albernaz et al., (1976):

. calibration of ocular movements; . research of spontaneous (open and closed eyes) and semi-spontaneous (open eye) nystagmus; . research of pendular path;

. research of optokinetic nystagmus;

. research of "pre" and "post" rotatory nystagmus with the decreasing pendular rotatory test, stimulating the semi circular lateral, anterior and posterior canals;

. research of the "pre" and "post" caloric nystagmus, accomplished with the subject positioned in a manner that the head and trunk are inclined 60 degrees backwards, in order for adequate stimulation of the semi circular canals to take place. The irrigation time of each ear with air at 42,18 and 10 degrees Celsius lasted 80 seconds for each temperature and the responses were registered with the eyes closed and subsequently with the eyes closed for the observation of the inhibitor effect of ocular fixation (EIFO). In this evaluation, the direction, the absolute values of the angular speed of the slow component (VACL) and the calculation of the ratios of the directional preponderance and labyrinthic predominance of post caloric nystagmus were observed.

Application of the Dizziness Handicap Inventory (DHI) questionnaire - Brazilian adaptation.

The above questionnaire was elaborated by Jacobson and Newman and culturally adapted to the Brazilian population by Castro (2003), as shown in Diagram 1.

The questionnaire was administered before and after RV e its objective was to verify the degree of handicap which dizziness induces in daily activities, and evaluate the emotional and functional aspects with nine questions each and the physical aspect with seven questions for a total of 25 questions. The answers permitted were "yes", worth 4 points, "sometimes", worth 2 points and "no", worth zero. The points system ranged from 0 to 100 , with the greater the value, the greater the handicap induced by dizziness in the patients' daily life.

Protocol of vestibular rehabilitation by Hawthorne (1944) and Cooksey (1946)

The exercises were carried out during 8 weeks, 
twice a day, at the retirement ward under the guidance and supervision of the speech therapist during two months. The exercises were envisioned to promote the return of static and dynamic equilibrium function, and also restoring spatial orientation. These exercises were accomplished with movement of the eyes, head and body in seated and orthostatic positions, demonstrated in Diagram 2.

This protocol was selected for the elderly subjects because of its straightforward administration and due to its implementation in groups it afforded more interaction among the subjects.

Statistical method: a descriptive analysis of the information from the anamnesis and vestibular evaluation was performed. For an analysis of the information from the DHI questionnaire - Brazilian adaptation, the Student T-Test was administered and a degree of significance of 0.05 or $5 \%$ was ratified for the rejection of any supposition of nullity.

\section{Results}

The hearing and vestibular complaints referred to in the anamnesis are shown in Graphs 1 and 2.

The occurrence of discovered changes in the evaluation of vestibular function is analysed in Table 1.

The conclusion of the vestibular exams is shown in Graph 3.

The results of the administration of the DHI questionnaire - Brazilian adaptation, before and after treatment, are analysed in Table 2.

The administration of the Student T-Test, comparing the evaluations before and after RV, resulted in the values $\mathrm{p}=0.00413$ (physical); $\mathrm{p}=$ 0.00006 (functional); $\mathrm{p}=0.03268$ (emotional) and $\mathrm{p}$ $=0.00081$ (total). Considering the significance level of $5 \%(a=0.05)$, it was verified that the result is significant for all aspects evaluated.

The extent, before and after treatment, of the physical, functional and emotional aspects are observed in Graph 4.

CHART 1. Questionnaire for dizziness handicap (Castro 2003)

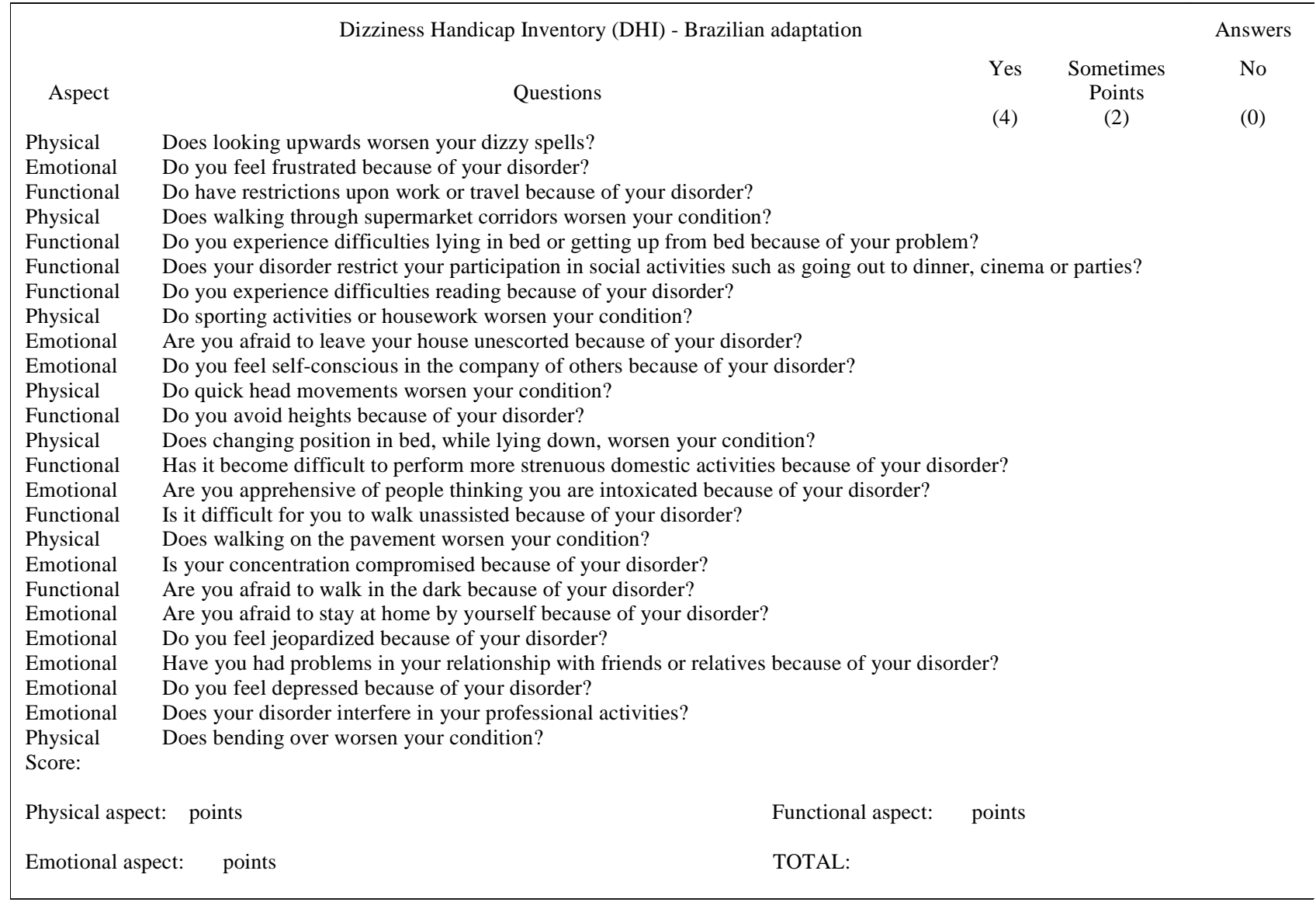


CHART 2. Cawthorne (1944) and Cooksey (1946) Exercises.

Head And Eye Movements in a Seated Position

1. Look upwards and downwards

2. Look to the right and to the left

3. Move your index finger towards the eye and then away from the eye (first slowly and then quickly)

4. With your eyes open, drop your head downwards and then roll it backwards (first slowly and then quickly)

5 . With your eyes open, roll your head to the left and to the right (first slowly and then quickly)

6. Repeat exercises 4 and 5 with your eyes closed

Head and Body Movements in a Seated Position

1. Place an object on the floor and pick it up, bending and extending your torso (looking at the object the entire time)

2. Bend your torso and move and object to the front and behind your knees.

Exercises in an Orthostatic Position

1. Sit and then rise to the orthostatic position with your eyes open

2. Repeat exercise 1 with your eyes closed

3. Repeat exercise 1 making a turn to the right in the orthostatic position

4. Repeat exercise 1 making a turn to the left in the orthostatic position

Activities for Improving Balance

1. Walk while rotating your neck to the left and to the right

2. In the orthostatic position, make brisk 90 degree turns with your body (first with your eyes open and then closed)

3. Go up and down the stairs (using the railing if necessary)

4. In the orthostatic position, stand on one foot (first with the right foot and then the left), with your eyes open and then closed

5. Stay in the orthostatic position upon a soft surface

6. Walk upon a soft surface

7. Make baby steps with your eyes open and then closed

8. Repeat exercise 4 upon a soft surface

GRAPH 1. Frequency of hearing complaints referred to in the anamnesis in eight elderly patients experiencing dizziness.

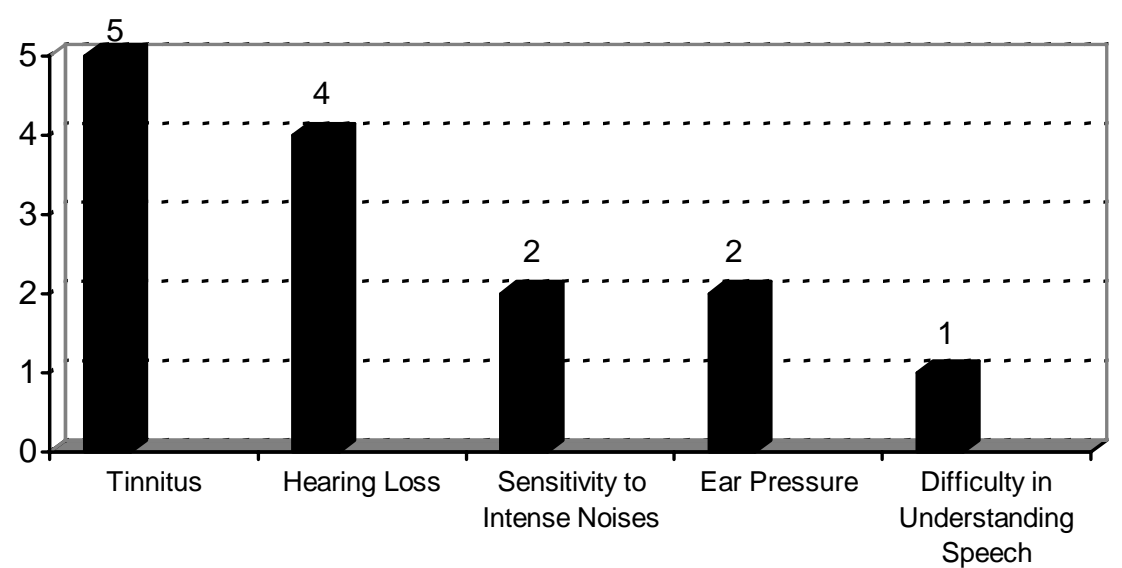


GRAPH 2. Frequency of vestibular complaints related in the anamneses of 8 elderly patients with dizziness.

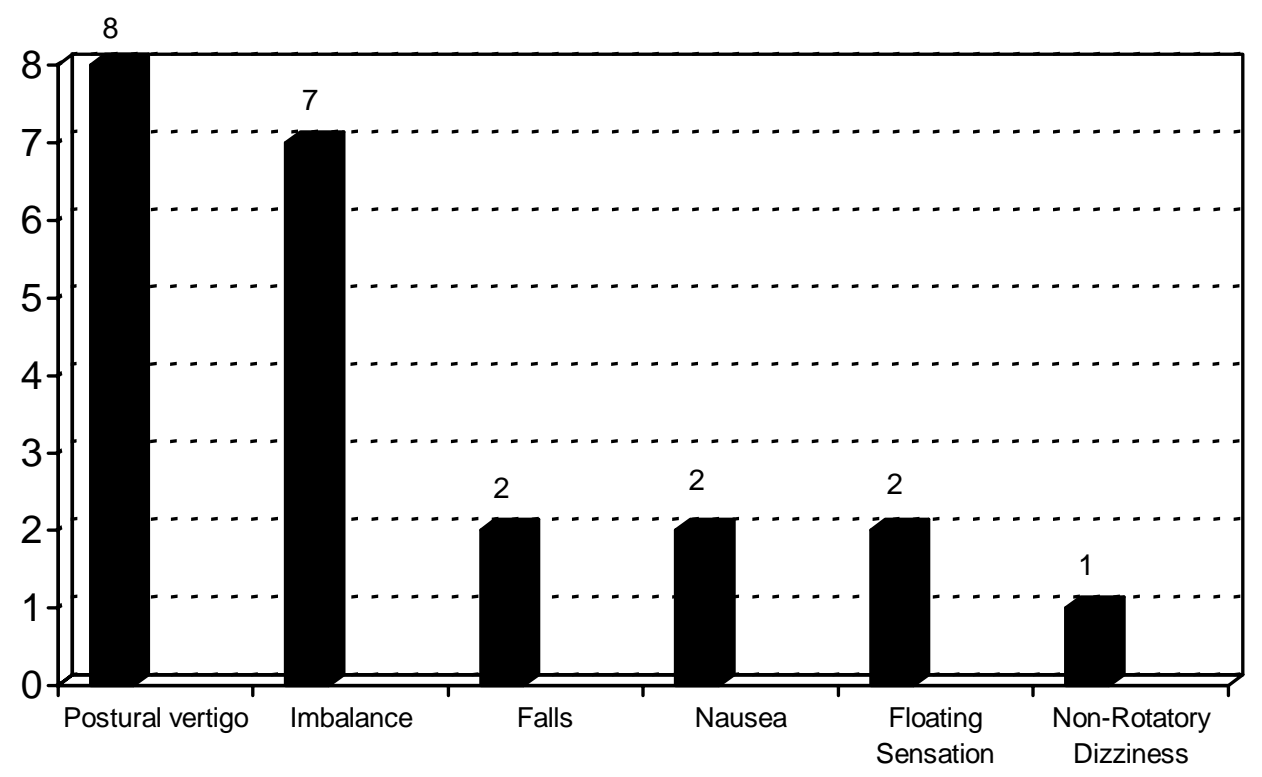

TABLE 1. Occurrence of abnormal findings in the vestibular exam in 8 elderly patients with dizziness.

\begin{tabular}{c|c}
\hline Findings & Occurrence \\
\hline Bilateral labyrinthian hyporeflexia & 4 \\
Unilateral labyrinthian hyporeflexia & 3 \\
Positional vertigo and/or nystagmus & 2 \\
Research of spontaneous nystagmus with eyes open & 1 \\
Per-rotatory nystagmus asymmetry (lateral ducts) & 1 \\
Bilateral labyrinthian hyporeflexia & 1 \\
Calibration of irregular ocular movements & 1 \\
\hline
\end{tabular}

GRAPH 3. Conclusion of vestibular exams in 8 elderly patients with dizziness.

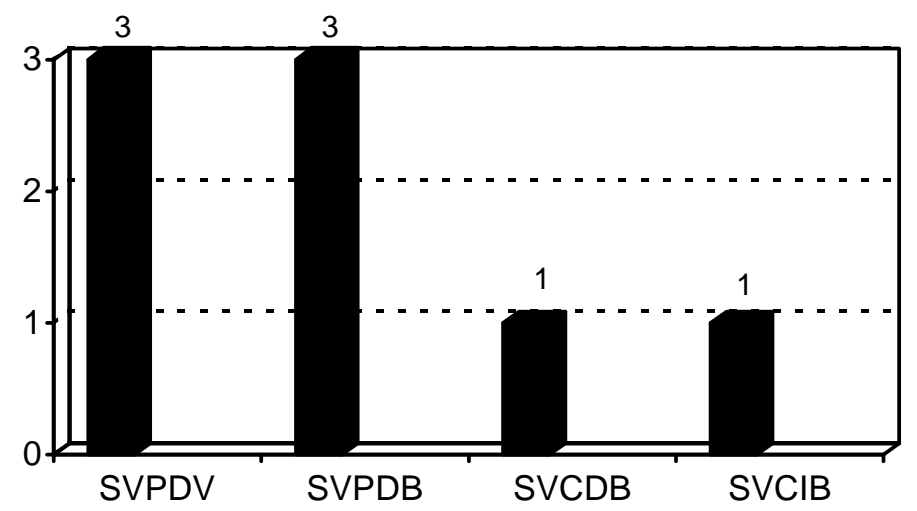

SVPDU - Unilateral Deficient Peripheral Vestibular Syndrome SVPDB - Bilateral Deficient Peripheral Vestibular Syndrome SVCDB - Bilateral Deficient Central Vestibular Syndrome SVCIB - Bilateral Irritative Central Vestibular Syndrome 
Pró-Fono Revista de Atualização Científica, v. 19, n. 2, abr.-jun. 2007

TABLE 2. Evaluation of the physical, functional and emotional aspects, before and after treatment, in 8 elderly patients with dizziness.

\begin{tabular}{|c|c|c|c|c|c|c|c|c|}
\hline \multirow[t]{2}{*}{ Patient } & \multicolumn{2}{|c|}{ Physical } & \multicolumn{2}{|c|}{ Functional } & \multicolumn{2}{|c|}{ Emotional } & \multicolumn{2}{|c|}{ TOTAL } \\
\hline & Before & After & Before & After & Before & After & Before & After \\
\hline 1 & 0 & 0 & 8 & 0 & 0 & 0 & 8 & 0 \\
\hline 2 & 4 & 0 & 2 & 0 & 2 & 0 & 8 & 0 \\
\hline 3 & 2 & 0 & 10 & 4 & 12 & 2 & 24 & 6 \\
\hline 4 & 12 & 6 & 6 & 2 & 0 & 0 & 18 & 8 \\
\hline 5 & 20 & 10 & 12 & 6 & 4 & 2 & 36 & 18 \\
\hline 6 & 14 & 2 & 6 & 0 & 6 & 0 & 26 & 2 \\
\hline 7 & 2 & 0 & 4 & 0 & 0 & 0 & 6 & 0 \\
\hline 8 & 20 & 10 & 8 & 4 & 20 & 4 & 48 & 18 \\
\hline Mean & 9,25 & 3,50 & 7,00 & 2,00 & 5,50 & 1,00 & 21,75 & 6,50 \\
\hline Standard & & & & & & & & \\
\hline Deviation & 8,28 & 4,50 & 3,21 & 2,39 & 7,15 & 1,51 & 14,91 & 7,69 \\
\hline
\end{tabular}

GRAPH 4. Comparison of the means of the physical, functional and emotional aspects, before and after treatment, in 8 elderly patients with dizziness.

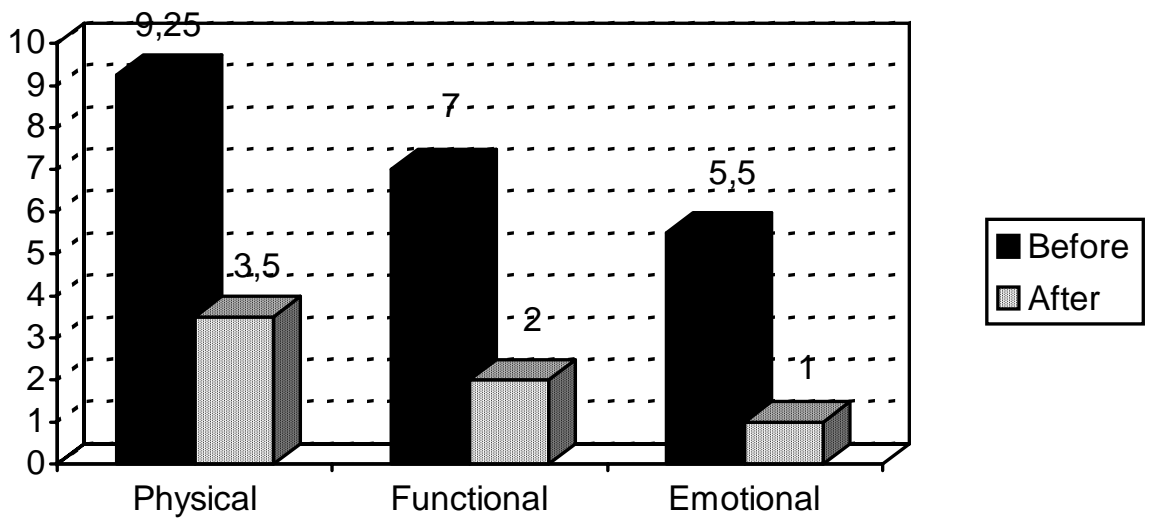




\section{Discussion}

As regards hearing and vestibular complaints, a major occurrence of tinnitus, hypoacusia, postural vertigo and imbalance was observed. These complaints were also proven by Gushikem (2001). There is a consensus within the literature that the occurrence of these symptoms is considered recurrent in the elderly population. In this population, an augmenting rise in disturbances of sensory functions, peripheral and central integration of information, as well as the aging of the neuromuscular systems and skeletal function, are observed (Simoceli et al., 2003).

Mota et al., (2002) relates that in people of an advanced age, the aging of the sensory systems should be taken into account, especially vision, proprioception, the receptors of plantar pressure and the internal ear function. In every level of these systems a neuron loss is produced which begins in the sixth decade and accelerates after 70. A neuronal loss also occurs in the cerebrum and cerebellum. Consequently the neuronal system, assigned for balance and vestibulo-oculomotor function, shows a gradual loss of speed and precision, manifested by giddiness and vertigo.

Another factor is the increasing inability of the cardiovascular system, which is responsible for supplying the central nervous system with oxygen and nutrients. Short episodes of cerebrovascular insufficiency can evoke vertigo crises, which can be uncontrollable, with a perception of rotation, instability and observable nystagmus.

Alterations have been proven in the vestibular exams of all the subjects evaluated.

The alterations were, in the majority, in the caloric test with labyrinthian hyporeactivity. In the vestibular exam, three cases of unilateral deficient peripheral vestibular syndrome, one case of bilateral deficient central vestibular syndrome and one case of bilateral irritating central vestibular syndrome were observed.

According to Nadol and Schuknecht (1989), the association of various causes to the concomitant decline of several systems responsible for the maintenance of corporal balance, and the difficulties in the compensation of these alterations, can be the factors responsible for the vestibular alterations (peripheral and/or central; irritating and/ or deficient) in the subjects. Six cases of alterations of the peripheral vestibular system and two cases of alteration of the central vestibular system were observed. Hyporeflexia is described by several authors as being a common finding in the vestibular evaluation of the subjects (Mota et al., 2002; Castro, 2003).

Various studies relate that the loss of ciliated cells from the ampullar crests and the maculae, the decline in the number nerve cells of the Scarpio ganglion, the degeneration of the otocones, the decline in the labyrinthian blood flow, the progressive depression of neural stability, the reduction in capacity of the vestibulo-ocular (responsible for maintaining stable vision during head movement) and vestibulospinal (responsible for corporal stabilization) reflexes, contribute to reducing the speed of eye movements of tracking and to rotational and caloric hyporeactivity of the vestibular system, at both the peripheral and central level (Hain et al., 2002; Silveira et al., 2002; Whitney, 2002).

After RV therapy, on analysis of the DHI Brazilian adaptation questionnaire, a significant improvement was shown in the physical functional and emotional aspects, as well as in the symptomatology of all the elderly subjects, and this was substantiated in the changes in scores which varied, before treatment, from six to 48 points, with a mean of 21.75 and standard deviation 14.91 and after treatment, from zero to 18 points, with a mean of 6.50 and a standard deviation of 7.69.

Analysing the physical, functional and emotional aspects before treatment, the findings of the physical aspects are a point variation from 0 to 20 , mean 9.25 and standard deviation 8.28 ; in the functional aspect a variation from two to 12 , mean 7.0 and standard deviation 3.21 and in the emotional a variation from 0 to 20, mean 5.50 and standard deviation 7.15. Analysing the physical, functional and emotional aspects after treatment, the findings of the physical aspects are a point variation from 0 to 10 , mean 3.50 and standard deviation 4.50; in the functional aspect a variation from 0 to 6 , mean 2.0 and standard deviation 2.39 and in the emotional a variation from 0 to 4 , mean 1.0 and standard deviation 1.51. Comparing the means before and after treatment, a decrease and a consequent significant improvement were observed in every aspect evaluated. Gill-Body et al., (2000) considered the DHI a measurement of specific condition which evaluates the healthy state of subjects with vestibulopathy. O 'Reilly et al., (2000) and Silveira et al., (2002) administered the same protocol used in this study and also the selective torso exercises according to the criteria 
by Davis (1996). An improvement in symptomatolgy and clinical prognosis was observed, in harmony with this study. Cesarani et al., (2004) related that exercises with quick head movements, due to the fact that they are more detectable by the sensory receptors of the vestibular system, show the best results. $R V$ is a therapeutic process which seeks to accelerate the mechanisms of central compensation by means of neuronal plasticity, obtained with the execution of repetitive exercises which endeavour to promote a significant reduction in the labyrinthian symptoms. RV does not trigger off side effects and improves the quality of life of the patient (Jauhar, 2001; Ganança et al., 2004). Cohen et al., (2000) related the paucity of studies associated with the quality of life of subjects with vestibular disorders.

Treatment with RV is increasingly being highlighted in the international literature, because in addition to improving the patient's balance, it also has a prophylactic function. In Brazil, in recent years, RV has been widely used and its protocols have been diversified and personalized to the needs of patients with vestibulopathy.

\section{References}

CASTRO, A. S. O. Dizziness handicap inventory: adaptação cultural para o português brasileiro, aplicação e reprodutibilidade e comparação com os resultados à vestibulometria. 2003. 80 f. Tese (Mestrado em Ciências da Reabilitação Neuromotora) Departamento de Fisioterapia da Univ. Bandeirante de São Paulo, S.P. CAWTHORNE, T. The physiological basis of head exercises. J. Chart. Soc. Physiother., v. 30, p.106-107, 1944.

CESARANI, A.; ALPINI, D.; MONTI, B. et al. The treatment of acute vertigo. Neurol. Sci., Milano, v. 24, n. 5, p.26-30, set., 2004.

COHEN, H.S.; KIMBALL, K.T.; ADAMS, A.S. Application of the vestibular disorders activities of daily living scale. Laryngosc., St. Louis, v. 110, n. 7, p. 1204-1209, jul., 2000. COOKSEY, F. S. Rehabilitation in vestibular injuries. Proc. Royal. Soc. Med., v. 39, p. 273-278, 1946.

DAVIES, M. P. Exatamente no centro. São Paulo: Manole, 1996.

GANANÇA, F. F.; GANANÇA, C. F. Reabilitação vestibular: princípios e técnicas. In: GANANÇA, M. M.; MUNHOZ, L. S. M.; CAOVILLA, H. H.; SILVA, M. L. G. Estratégias terapêuticas em otoneurologia. São Paulo: Atheneu, 2001. p. 33-54.
Another point observed was the rise in motivation, integration and socialization of the elderly subjects when practising the exercises in groups. Rezende et al., (2003) demonstrated that $\mathrm{RV}$ in groups has been proven to be an extremely important therapeutic course with improvements in affability and social integration.

\section{Conclusion}

There were significant improvements in the evaluations of the physical, functional and emotional aspects after administration of the RV exercises.

The occurrence of hearing and vestibular variance in the elderly population justifies a systematic completion of an oto neurological evaluation. The success of treatment with labyrinthic rehabilitation requires the patient's cooperation and his active participation, inducing a positive psychological effect with repercussions in physical and psychic self-confidence and a consequent improvement in the quality of life.
GANANÇA, F. F.; CASTRO, A. S. O.; BRANCO, F. C.; NATOUR, J. Interferência da tontura na qualidade de vida de pacientes com síndrome vestibular periférica. $R$. Bras. Otorrinolaringol., São Paulo, v. 70, n. 1, p. 94-101, janfev, 2004. Disponível em: <http://www.scielo.br scielo.php?pid=S003472992004000100016\&script=sci_arttext\&t $>$. Acesso em: 2 jan. 2006.

GILL-BODY, K. M.; BENINATO, M.; KREBS, D. E. Relationship among balance impairmentes, functional performance and disability in people with peripheral vestibular hypofunction. Physical Ther, v. 80, n. 8, p. 748-758, 2000.

GUCCIONE, A. A. Fisioterapia geriátrica. 2. ed. Rio de Janeiro: Guanabara Koogan, 2002.

GUSHIKEM, P. Avaliação otoneurológica em idosos com tontura. 2001. $84 \mathrm{f}$. Tese (Mestrado em Distúrbios da Comunicação Humana) - Departamento de Otorrinolaringologia e Distúrbios da Comunicação Humana da Universidade Federal de São Paulo, São Paulo. HAIN. T. C.; RAMASWAMY, T. S.; HILLMAN, M. A. Anatomia e fisiologia do sistema vestibular normal. In: HERDMAN, S. J. Reabilitação vestibular. 2. ed. São Paulo: Manole, 2002. p. 3-24. 
JACOBSON, G. P.; NEWMAN, C. W. The development of the dizziness handicap inventory. Arch. Otolaryngol. Head. Neck. Surg., Chicago, v. 152, n. 6, p. 386-391, apr., 1990.

JAUHAR, S. Life out of balance. New York Mag., New York, v. 6, p. 1-7, dec. 2001.

JORNAL GAZETA DO POVO. O crescimento da população idosa no Brasil. JORNAL GAZETA DO POVO. Curitiba. Saúde. Disponível em: <http:// www.gazetadopovo.com.br> Acesso em: 28 mar. 2005.

JURKIEWICZ, A. L.; ZEIGELBOIM, B. S.; MANGABEIRA-ALBERNAZ, P. L. Alterações vestibulares em processos infecciosos do sistema nervoso central. Dist. Comun., São Paulo, v. 14, n. 1, p. 27-48, dez. 2002.

MANGABEIRA-ALBERNAZ, P. L.; GANANÇA, M. M.; PONTES, P. A. L. Modelo operacional do aparelho vestibular. In: MANGABEIRA-ALBERNAZ, P. L.; GANANÇA, M. M. Vertigem. $2^{\circ}$.ed. São Paulo: Moderna, 1976. p. 29-36

MOTA, P. H. M.; FRANCO, E. S.; et al. Estudo do equilíbrio no idoso por meio da electronistagmografia. Acta Awho, São Paulo, v. 21, n.3, p. 1-12, jun-dez., 2002. Disponível e m: <http://www.actaawho.com.br/edicao/ conteudo.asp?edi_id=6\&tpc_id=1\&con_id=19>Acesso em 06 abr. 2005.

NADOL, J. B.; SCHUKNECHT, H. J. The pathology of peripheral vestibular disorders in the elderly. Ear. Nose. Throat. J., New York, v. 68, n. 12, p. 930-934, mar., 1989.
O'REILLY, R. C.; ELFORD, B.; SLATER, R. Efectiveness of particle repositioning maneuvers in subtypes of benign paroxysmal positional vertigo. Laryngosc., St. Louis, v. 110 , n. 8, p. 1385-1388, aug. 2000.

REZENDE, C.R.; TAGUCHI, C.K.; ALMEIDA, J.G. et al. Reabilitação vestibular em pacientes idosos portadores de vertigem posicional paroxístitca benigna. R. Bras. Otorrinol., São Paulo, v. 69, n. 34, p. 34-38, jul-ago., 2003.

SILVEIRA, S. R.; TAGUCHI, C. K.; GANANÇA, F. F. Análise comparativa de duas linhas de tratamento para pacientes portadores de síndromes vestibulares periféricas com idade superior a sessenta anos. Acta Awho. São Paulo, v. 21, n. 1, p. 1-13, jan-mar., 2002. Disponível em:<http:/ / w w w. a c t a a w ho.com.br/ed i c a o / conteudo.asp?edi_id=4\&tpc_id=1\&con_id=1.> Acesso em: 6 abr. 2005.

SIMOCELI, L.; BITTAR, R.M.S.; BOTTINO, M.A.; BENTO, R.F. Perfil diagnóstico do idoso portador de desequilíbrio corporal: resultados preliminares. R. Bras. Otorrinolaringol., São Paulo, v. 69, n. 6, p. 772-777, nov-dez., 2003.

ZEIGELBOIM, B. S.; JURKIEWICZ, A. L.; FUKUDA, Y. et al. Alterações vestibulares em doenças degenerativas do sistema nervoso central. Pró-Fono R. Atual. Cient., Carapicuiba (SP), v. 13, n. 2, p. 263-270, set., 2001.

ZEIGELBOIM, B. S.; JURKIEWICZ, A. L.; BITENCOURT, R. F. et al. Alterações vestibulares em doenças vasculares com envolvimento do sistema nervoso central. Fono Atual, São Paulo, v. 7, n. 7, p. 43-57, jan-mar., 2004.

WHITNEY, S. L. Tratamento do idoso com disfunção vestibular. In: HERDMAN, S. J. Reabilitação vestibular. 2. ed. São Paulo: Manole, 2002. p. 505-528. 